\title{
Strength Characterization of E-glass Fiber Reinforced Epoxy Composites with Filler Materials
}

\author{
K. Devendra ${ }^{1}$, T. Rangaswamy ${ }^{2}$ \\ ${ }^{1}$ Department of Mechanical Engineering, SKSVMACET, Laxmeshwar, India \\ ${ }^{2}$ Department of Mechanical Engineering, Government Engineering College (GEC), Hassan, India \\ Email: devenk93@gmail.com
}

Received September 2, 2013; revised October 17, 2013; accepted October 28, 2013

Copyright (C) 2013 K. Devendra, T. Rangaswamy. This is an open access article distributed under the Creative Commons Attribution License, which permits unrestricted use, distribution, and reproduction in any medium, provided the original work is properly cited.

\begin{abstract}
In this research work, an investigation was made on the mechanical properties of E-glass fiber reinforced epoxy composites filled by various filler materials. Composites filled with varying concentrations of fly ash, aluminum oxide $\left(\mathrm{Al}_{2} \mathrm{O}_{3}\right)$, magnesium hydroxide $\left(\mathrm{Mg}(\mathrm{OH})_{2}\right)$ and hematite powder were fabricated by standard method and the mechanical properties such as ultimate tensile strength, impact strength and hardness of the fabricated composites were studied. The test results show that composites filled by $10 \%$ volume $\mathrm{Mg}(\mathrm{OH})_{2}$ exhibited maximum ultimate tensile strength and hardness. Fly ash filled composites exhibited maximum impact strength.
\end{abstract}

Keywords: Composites; Fillers; Mechanical; Properties; Strength

\section{Introduction}

Polymers have replaced many of the conventional metals/materials in various applications. This is possible because of the advantages such as ease of processing, productivity, cost reduction, etc. offered by polymers over conventional materials. In most of these applications, the properties of polymers are modified by using fibers to suit the high strength/high modulus requirements. The high performance of continuous fiber (e.g. carbon fiber, glass fiber) reinforced polymer matrix composites is well known and documented [1]. Among the thermosetting polymers, epoxy resins are the most widely used for high-performance applications, such as matrices for fiber reinforced composites, coatings, structural adhesives and other engineering applications. Epoxy resins are characterized by excellent mechanical and thermal properties, high chemical and corrosion resistance, low shrinkage on curing and the ability to be processed under a variety of conditions [2]. However, these composites have some disadvantages related to the matrix dominated properties which often limit their wide applications. In the industry, the addition of filler materials to a polymer is a common practice. This improves not only stiffness, toughness, hardness, heat distortion temperature, and mold shrinkage, but also reduces the processing cost significantly. In fact, more than $50 \%$ of all produced polymers are in one way or another filled with inorganic fillers to achieve the desired properties [3]. Mechanical properties of fiberreinforced composites are depending on the properties of the constituent materials (type, quantity, fiber distribution and orientation, void content). Beside those properties, the nature of the interfacial bonds and the mechanisms of load transfer at the interphase also play an important role [4]. Nowadays specific fillers/additives are added to enhance and modify the quality of composites as these are found to play a major role in determining the physical properties and mechanical behavior of the composites. For many industrial applications of glass fiber reinforced epoxy composite, information about their mechanical behavior is of great importance. Therefore, in this work, the mechanical behavior of E-glass fiber reinforced epoxy composites filled by varying concentration of fly ash $\mathrm{Al}_{2} \mathrm{O}_{3}, \mathrm{Mg}(\mathrm{OH})_{2}$ and hematite powder has been studied.

\section{Experimentation}

\subsection{Materials for Composites}

ARALDITE (L-12) epoxy had been used as matrix material for reinforced composites in this experimental work. For reinforcing epoxy matrix, E-glass fiber was used along with hardener K-6. Fly ash, $\mathrm{Al}_{2} \mathrm{O}_{3}, \mathrm{Mg}(\mathrm{OH})_{2}$ and hematite powder was used as filler materials. Fly ash was 
obtained from thermal power plant. Measured density of fly ash particles was $2.0 \mathrm{~g} / \mathrm{cc}$. These micron-sized elements are consists primarily of silica $(59.5 \%)$, alumina $(20.3 \%), \mathrm{Fe}_{2} \mathrm{O}_{3}(6.5 \%)$, titanium (1.28\%), potassium oxide $(0.96 \%), \mathrm{MgO}(0.50 \%)$, Phosphates $(0.05 \%)$, Sulfates $(0.345 \%)$ and unburned coal [5]. Most of these particles have a gas bubble at the center. Aluminum oxide particles is a ceramic powder commonly used filler, it is also used as an abrasive due to its hardness. Magnesium hydroxide is an inorganic compound and it is a white powder with specific gravity of 2.36 , very slightly soluble in water; decomposing at $350^{\circ} \mathrm{C}$. Magnesium hydroxide is attracting attention because of its performance, price, low corrosiveness and low toxicity. Hematite is an iron oxide with the same crystal structure as that of corundum (rubies and sapphires). Usually the color varies between a metallic grey and red. Hematite is one of the oldest stones mined in our history.

\subsection{Fabrication of Composites}

The E-glass/Epoxy based composite slabs filled with varying concentrations of $(0 \%, 10 \%$ and $15 \%$ volume $)$ fly ash, aluminum oxide $\left(\mathrm{Al}_{2} \mathrm{O}_{3}\right)$, magnesium hydroxide $\left(\mathrm{Mg}(\mathrm{OH})_{2}\right)$, and hematite powder were prepared. The volume fraction of fiber, epoxy and filler materials were determined by considering the density, specific gravity and mass. Fabrication of the composites is done at room temperature by hand lay-up techniques. The required ingredients of resin, hardener, and fillers are mixed thoroughly in a basin and the mixture is subsequently stirred constantly. The glass fiber positioned manually in the open mold. Mixture so made is brushed uniformly, over the glass plies. Entrapped air is removed manually with squeezes or rollers to complete the laminates structure and the composite is cured at room temperature.

\subsection{Specimen Preparation}

The prepared E-glass fiber reinforced epoxy composite slabs filled by various filler materials were taken out from the mold and then specimens of suitable dimensions were prepared from the composite slabs for different mechanical tests according to ASTM standards. The test specimens were cut by slabs by using diamond tipped cutter and different tools in the work shop. Three identical test specimens were prepared for different test. Designation and composition of prepared composite slabs are presented in Table 1.

\section{Mechanical Property Testing}

Mechanical properties of composites were evaluated by tensile, impact and hardness measurements. Tensile, impact and hardness tests were carried out using Universal testing machine, impact machine and hardness testing
Table 1. Designation and compositions of fabricated composites.

\begin{tabular}{cccc}
\hline $\begin{array}{c}\text { Material } \\
\text { Designation }\end{array}$ & $\begin{array}{c}\text { Glass Fiber } \\
\text { (Volume \%) }\end{array}$ & $\begin{array}{c}\text { Epoxy } \\
\text { (Volume \%) }\end{array}$ & $\begin{array}{c}\text { Filler Materials } \\
\text { (Volume \%) }\end{array}$ \\
\hline $\mathrm{GE}$ & 50 & 50 & Nil \\
$\mathrm{GEF}_{1}$ & 50 & 40 & $10 \%$ Fly ash \\
$\mathrm{GEF}_{2}$ & 50 & 35 & $15 \% \mathrm{Fly}$ ash \\
$\mathrm{GEA}_{1}$ & 50 & 40 & $10 \% \mathrm{Al}_{2} \mathrm{O}_{3}$ \\
$\mathrm{GEA}_{2}$ & 50 & 35 & $15 \% \mathrm{Al}_{2} \mathrm{O}_{3}$ \\
$\mathrm{GEM}_{1}$ & 50 & 40 & $10 \% \mathrm{Mg}(\mathrm{OH})_{2}$ \\
$\mathrm{GEM}_{2}$ & 50 & 35 & $15 \% \mathrm{Mg}(\mathrm{OH})_{2}$ \\
$\mathrm{GEH}_{1}$ & 50 & 40 & $10 \% \mathrm{Hematite} \mathrm{Powder}$ \\
$\mathrm{GEH}_{2}$ & 50 & 35 & $15 \%$ Hematite Powder \\
\hline
\end{tabular}

machine respectively. Three identical samples were tested for tensile strength, impact strength and hardness.

\subsection{Ultimate Tensile Strength}

Tensile tests were examined according to ASTM D3039 using a universal testing machine at room temperature. Test specimens having dimension of length $250 \mathrm{~mm}$, width of $25 \mathrm{~mm}$ and thickness of $2.5 \mathrm{~mm}$. The specimen was loaded between two manually adjustable grips of a $60 \mathrm{KN}$ computerized universal testing machine (UTM) with an electronic extensometer. Test was repeated thrice and the average value was taken to calculate the tensile strength of the composites.

\section{Details of Universal Testing Machine}

Universal testing machine is a Micro Control Systems make and model MCS-UTE60 and software used is MCSUTE STDW2KXP. System uses add-on cards for data acquisition with high precision and fast analog to digital converter for pressure/Load cell processing and rotary encoder with 0.1 or $0.01 \mathrm{~mm}$ for measuring cross head displacement (RAM stroke). These cards are fitted on to slots provided on PC's motherboard WINDOW9X based software is designed to fulfill nearly all the testing requirements. MCS make electronic extensometer is used with an extremely accurate strain sensor for measuring the strain of the tensile samples.

\subsection{Impact Strength}

The Charpy impact strength was carried out on composites in accordance with ASTM E23 using impact testing machine. The dimensions of the specimens were $10 \mathrm{~mm}$ $\times 10 \mathrm{~mm} \times 55 \mathrm{~mm}$ size on one side surface of the specimen a V-notch have been made at an angle of $45^{\circ}$ with root depth of $2 \mathrm{~mm}$. Test was repeated thrice and the average values were taken for calculating the impact strength.

\subsection{Brinell Hardness Test}

Brinell hardness test was conducted on the specimen 
using a standard Brinell hardness tester. A load of $250 \mathrm{~kg}$ was applied on the specimen for $30 \mathrm{sec}$ using $5 \mathrm{~mm}$ diameter hard metal ball indenter and the indentation diameter was measured using a microscope. The hardness was measured at three different locations of the specimen and the average value was calculated. The indentation was measured and hardness was calculated using Equation (1).

$$
B H N=\frac{2 P}{\pi D\left(D-\sqrt{\left(D^{2}-d^{2}\right)}\right)}
$$

where: $P=$ Applied force $(\mathrm{Kgf}) ; D=$ Diameter of indenter $(\mathrm{mm}) ; d=$ Diameter of indentation $(\mathrm{mm})$.

\section{Results and Discussion}

Results obtained from this experimental work are presented in Tables 2-4 and Figures 1-3. Mechanical properties of fiber-reinforced epoxy composites are depending on the properties of the constituent materials (type, quantity, fiber distribution and orientation, void content). Beside those properties, the nature of the interfacial bonds and the mechanisms of load transfer at the inter phase also play an important role.

\subsection{Ultimate Tensile Strength}

The tensile strength of the E-glass fiber reinforced epoxy composites depends upon the strength and modulus of

Table 2. Comparison of ultimate tensile strength.

\begin{tabular}{cc}
\hline Composite materials & Ultimate Tensile Strength, (MPa) \\
\hline $\mathrm{GE}$ & 450.24 \\
$\mathrm{GEF}_{1}$ & 249.80 \\
$\mathrm{GEF}_{2}$ & 168.80 \\
$\mathrm{GEA}_{1}$ & 297.80 \\
$\mathrm{GEA}_{2}$ & 257.21 \\
$\mathrm{GEM}_{1}$ & 375.36 \\
$\mathrm{GEM}_{2}$ & 347.20 \\
$\mathrm{GEH}_{1}$ & 156.92 \\
$\mathrm{GEH}_{2}$ & 182.30 \\
\hline
\end{tabular}

Table 3. Comparison of Charpy impact strength.

\begin{tabular}{cc}
\hline Composite materials & Charpy Impact Strength $\left(\mathrm{J} / \mathrm{mm}^{2}\right)$ \\
\hline $\mathrm{GE}$ & 0.2846 \\
$\mathrm{GEF}_{1}$ & 0.2041 \\
$\mathrm{GEF}_{2}$ & 0.1500 \\
$\mathrm{GEA}_{1}$ & 0.1681 \\
$\mathrm{GEA}_{2}$ & 0.1575 \\
$\mathrm{GEM}_{1}$ & 0.1687 \\
$\mathrm{GEM}_{2}$ & 0.1625 \\
$\mathrm{GEH}_{1}$ & 0.1250 \\
$\mathrm{GEH}_{2}$ & 0.1583 \\
\hline
\end{tabular}

Table 4. Comparison of Brinell hardness number.

\begin{tabular}{cc}
\hline Composite materials & Hardness (BHN) \\
\hline $\mathrm{GE}$ & 57.64 \\
$\mathrm{GEF}_{1}$ & 39.68 \\
$\mathrm{GEF}_{2}$ & 37.11 \\
$\mathrm{GEA}_{1}$ & 73.90 \\
$\mathrm{GEA}_{2}$ & 82.13 \\
$\mathrm{GEM}_{1}$ & 88.69 \\
$\mathrm{GEM}_{2}$ & 88.10 \\
$\mathrm{GEH}_{1}$ & 46.86 \\
$\mathrm{GEH}_{2}$ & 54.25 \\
\hline
\end{tabular}

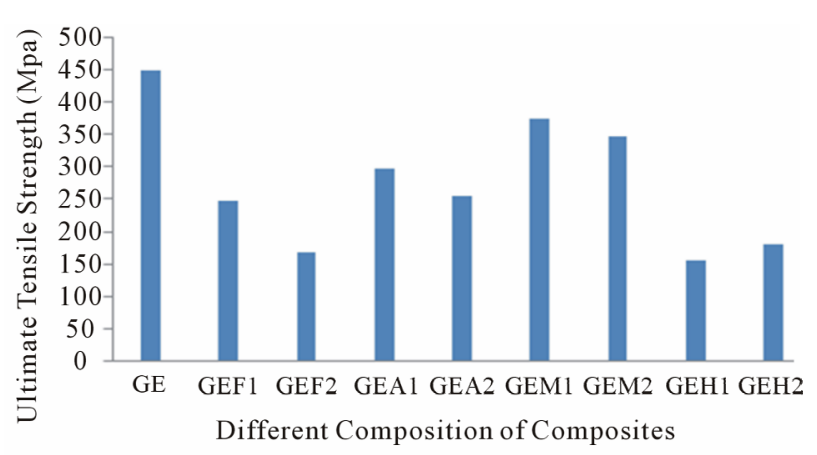

Figure 1. Ultimate tensile strength for different composition of composite materials.

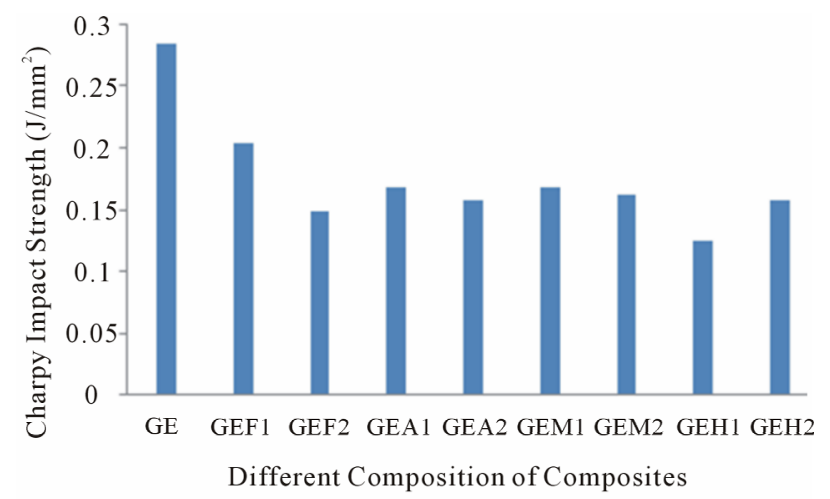

Figure 2. Charpy impact strength for different composition of composite materials.

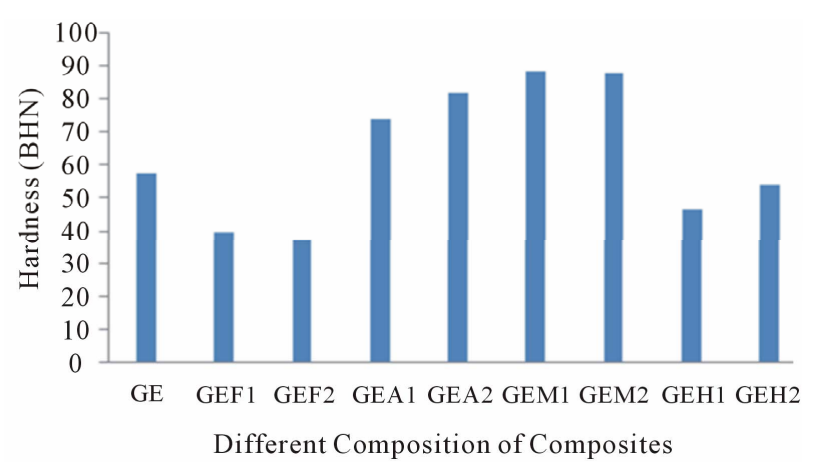

Figure 3. Brinell hardness number for different composition of composite material. 
the fibers, strength and chemical stability of the matrix, fiber matrix interaction and fiber length.

From the obtained results it was observed that composite filled by $10 \%$ Volume $\operatorname{Mg}(\mathrm{OH})_{2}$ exhibited maximum ultimate strength of $375.36 \mathrm{MPa}$ when compared with other filled composites but lower than the un filled composite [Figure 1]. This may be due to good particle dispersion and strong polymer/filler interface adhesion for effective stress transfer. Composites filled by $\mathrm{Al}_{2} \mathrm{O}_{3}$ exhibited better ultimate tensile strength compared with composites filled by fly ash and hematite this is due to that $\mathrm{Al}_{2} \mathrm{O}_{3}$ having the ceramic particles these particles distributed uniformly throughout the composites and produces good bonding strength between polymer, filler and fiber. But increase in addition of $\mathrm{Mg}(\mathrm{OH})_{2}, \mathrm{Al}_{2} \mathrm{O}_{3}$ and fly ash content up to $15 \%$ volume to the composites the tensile strengths is found to be less this is due to more filler material in the composites damages matrix continuity, less volume of fiber and more void formation in the composites. Ultimate tensile strength increases with increase in addition of hematite to composites this may be due to improved in inter facial bonding strength between filler, matrix and fiber.

\subsection{Impact Strength}

Impact strength is defined as the ability of a material to resist the fracture under stress applied at high speed. The impact properties of composite materials are directly related to overall toughness and composite fracture toughness is affected by inter laminar and interfacial strength parameters.

From Figure 2, it is observed that composite filled by $10 \%$ volume fly ash having high impact strength when compared with other filled composites this is due to that good bonding strength between filler, matrix, fiber and flexibility of the interface molecular chain resulting in absorbs and disperses the more energy, and prevents the cracks initiator effectively. But there was reduction in impact resistance as the fly ash content increases which might be because of formation of additional voids and this void increases the crack propagation. Impact strength decreases when increase in addition of $\mathrm{Al}_{2} \mathrm{O}_{3}$ and $\mathrm{Mg}(\mathrm{OH})_{2}$ to composites. Typically, a polymer matrix with high loading of fillers has less ability to absorb impact energy this is because the fillers disturb matrix continuity and each fillers is a site of stress concentration, which can act as a micro crack initiator and reduces the adhesion and energy absorption capacity of composites. Test results show that impact strength increases with adding more hematite powder to composites this due to improvement of bonding strength between filler and matrix and rigidity of filler particles absorbs the more energy.

\subsection{Hardness}

Hardness properties of all the composites are presented

\section{in the Table 4.}

The experimental results show that composite filled by $10 \%$ volume $\mathrm{Mg}(\mathrm{OH})_{2}$ exhibited maximum hardness number of 88.69 BHN when compared with other filled composites this due to uniform dispersion of $\mathrm{Mg}(\mathrm{OH})_{2}$ particles and good bonding strength between fiber and matrix [6]. From Figure 3, it is observed that increase in addition of $\mathrm{Al}_{2} \mathrm{O}_{3}$ and hematite to composites leads to increase in hardness number this may be due to the improved bond between the matrix and reinforcement, reduced porosity. When increasing the particle loading in the matrix decreases the inter particle distance with results in increase of resistance to indentation. Fly ash filled composites exhibited less hardness number this due to weak bonding strength and more possibility of void formation.

\section{Conclusions}

Based upon the test results obtained from the various tests carried out, following conclusions were made:

1) From the obtained results, it was observed that composite filled by $10 \%$ volume of $\mathrm{Mg}(\mathrm{OH})_{2}$ exhibited maximum ultimate strength of $375.36 \mathrm{MPa}$ when compared with other filled composites. Composites filled by $\mathrm{Al}_{2} \mathrm{O}_{3}$ exhibited better ultimate strength compared with composites filled by fly ash and hematite. Increase in addition of $\mathrm{Mg}(\mathrm{OH})_{2}, \mathrm{Al}_{2} \mathrm{O}_{3}$ and fly ash to composites leads to decrease in ultimate tensile strength.

2) Experimental results show that composites were filled by $10 \%$ volume of fly ash having high impact strength when compared with other filled composites. Composites filled by $10 \%$ volume $\mathrm{Al}_{2} \mathrm{O}_{3}$ and $\mathrm{Mg}(\mathrm{OH})_{2}$ exhibited good impact strength but increase in addition of $\mathrm{Al}_{2} \mathrm{O}_{3}$ and $\mathrm{Mg}(\mathrm{OH})_{2}$ leads to decrease in impact strength. Test results indicated that impact strength increases with adding more hematite powder to composites.

3) The experimental results indicated that composite filled by $\mathrm{Mg}(\mathrm{OH})_{2}$ exhibited maximum hardness number 88.69 BHN when compared with other filled composites. From the results, it is observed that increase in addition of $\mathrm{Al}_{2} \mathrm{O}_{3}$ and hematite to composites increases the hardness of the composites. Increase in addition of fly ash to composites leads to decrease in hardness number.

\section{REFERENCES}

[1] A. Yasmin and I. M. Daniel, "Mechanical and Thermal Properties of Graphite Platelet/Epoxy Composites," Polymer, Vol. 45, No. 24, 2004, pp. 8211-8219. http://dx.doi.org/10.1016/j.polymer.2004.09.054

[2] N. Hameed, P. A. Sreekumar, B. Francis, W. Yang and S. Thomas, "Morphology, Dynamic Mechanical and Thermal Studies on Poly(styrene-co-acrylonitrile) Modified Epoxy Resin/Glass Fibre Composites," Composites Part 
A, Vol. 38, No. 12, 2007, pp. 2422-2432. http://dx.doi.org/10.1016/j.compositesa.2007.08.009

[3] R. N. Rothon, "Mineral Fillers in Thermoplastics: Filler Manufacture and Characterization," Advances in Polymer Science, Vol. 139, 1999, pp. 67-107.

[4] Cs. Varga, N. Miskolczi, L. Bartha and G. Lipoczi, "Improving the Mechanical Properties of Glass-Fibre-Reinforced Polyester Composites by Modification of Fibre Surface," Materials and Design, Vol. 31, 2010, pp. 185-
193.

[5] M. Single and V. Chawla, "Mechanical Properties of Epoxy Resin-Fly Ash Composite," Journal of Minerals and Materials Characterization and Engineering, Vol. 9, No. 3, 2010, pp. 199-210.

[6] R. K. Goyal, A. N. Tiwari and Y. S. Negi, "Micro Hardness of PEEK/Ceramic Micro- and Nano Composites: Correlation with Halpin-Tsai Model," Materials Science and Engineering, Vol. 491, No. 1-2, 2008, pp. 230-236. 